\title{
PERANCANGAN APLIKASI SISTEM PRESENSI KARYAWAN BERBASIS WEB DI PT. PWS REINSURANCE BROKER INDONESIA
}

\author{
Ardyansyah Putra Pratama ${ }^{1 *}$, Verdi Yasin ${ }^{2}$, Anton Zulkarnaen Sianipar ${ }^{3}$ \\ Program Studi Teknik Informatika, STMIK Jayakarta \\ Jalan. Salemba I No.10, RT.4/RW.6, Kenari, Kec. Senen, Jakarta Pusat 10430 Indonesia \\ *e-mail: 17570034@stmik.jayakarta.ac.id, verdiyasin29@gmail.com, antonz@stmik.jayakarta
}

Received: July 25, 2021, Revised: August 16, 2021 Accepted: August 25, 2021

\begin{abstract}
Abstrak
Presensi atau biasa disebut juga absensi adalah sebuah kegiatan pengambilan data guna mengetahui jumlah kehadiran pada suatu acara. Hal ini butuhkan baik oleh suatu Instansi pemerintahan maupun kantor swasta untuk berlangsungnya kegiatan operasional di dalamnya. PT. PWS Reinsurance Broker Indonesia adalah perusahaan yang bergerak dibidang perasuransian. Namun untuk pencatatan kehadiran karyawan yang diterapkan masih menggunakan cara manual yakni menggunakan pencatatan didalam software Microsoft excel dan jika hadir diperusahaan tersebut hanya tatap muka. Hal dinilai kurang begitu efektif dan efisien dalam menunjang produktivitas kerja para pegawai di dalamnya. Dari permasalahan tersebut memunculkan gagasan untuk membuat suatu aplikasi berbasis web, yang di dalamnya dapat melakukan pengelolaan data kehadiran karyawan diperusahaan tersebut. Metodologi yang digunakan dalam pembuatan aplikasi ini adalah metode Waterfall. Bahasa pemrogramannya adalah PHP dan HTML. Untuk tampilan menggunakan CSS3 dan Jquery. Databasenya menggunakan MySQL Tools dan Editor yang digunakan ialah XAMPP for Windows 5.6.36, Viual Studio Code. Didukung dengan tersedianya jaringan internet lokal di dalam perusahaan. Aplikasi ini nantinya akan digunakan sebagai media pencatatan kehadiran karyawan dan dapat diterapkan langsung sebagai solusi dalam meningkatkan kinerja dengan sistem yang terintegrasi sehingga dapat menghasilkan laporan data kehadiran karyawan yang cepat, akurat dan tentunya efisien.
\end{abstract}

Kata kunci: PWS Reinsurance Broker Indonesia ,Sistem Presensi, PHP, MySql, Database.

\begin{abstract}
Attendance or commonly called attendance is a data collection activity to find out the number of attendance at an event. This is required by both a government agency and a private office for operational activities to take place in it. PT. PWS Reinsurance Broker Indonesia is a company engaged in insurance. However, for recording employee attendance, it is still applied manually, namely using recording in Microsoft Excel software and if present at the company, only face to face. This is considered less effective and efficient in supporting the work productivity of the employees in it. From these problems led to the idea to create a web-based application, in which it can manage employee attendance data in the company. The methodology used in making this application is the Waterfall method. The programming languages are PHP and HTML. For display using CSS3 and Jquery. The database uses MySQL Tools and the editor used is XAMPP for Windows 5.6.36, Viual Studio Code. Supported by the availability of a local internet network within the company. This application will later be used as a medium for recording employee attendance and can be applied directly as a solution in improving performance with an integrated system so that it can produce employee attendance data reports that are fast, accurate and of course efficient..
\end{abstract}

Keywords: PWS Reinsurance Broker Indonesia, Attendance System, PHP, MySql, Database.

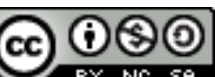




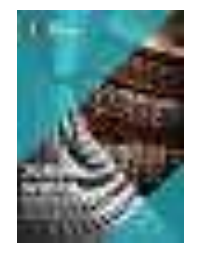

Jurnal Widya

Volume 2, Nomor 2,Oktober 2021: halaman 115-128

P-ISSN: $2746-5411$

e-ISSN: 2807-5528

https://jurnal.amikwidyaloka.ac.id/index.php/awl

jurnal@amikwidyaloka.ac.id/ editor.jurnalwidya@gmail.com

\section{Pendahuluan (Introduction)}

Presensi atau biasa disebut juga absensi adalah sebuah kegiatan pengambilan data guna mengetahui jumlah kehadiran pada suatu acara. Setiap kegiatan yang membutuhkan informasi mengenai peserta tentu akan melakukan absensi. Seperti dokumen yang mencatat jam hadir setiap karyawan di perusahaan. Catatan jam hadir karyawan tersebut dapat berupa daftar hadir biasa, dapat juga pula berbentuk kartu hadir yang diisi dengan mesin pencatat waktu. Pekerjaan mencatat waktu pada dasarnya dapat dipisahkan menjadi 2(dua) bagian yakni pencatatan waktu hadir (attendance time keeping) dan juga pencatatan waktu kerja (shop time keeping). PWS Reinsurance Broker Indonesia berdiri sejak tahun 2010 tepatnya 6 September. Perusahaan ini bergerak dibidang perasuransian. Data kehadiran karyawan PT. PWS Reinsurance Broker Indonesia, sistem yang diterapkKan dalam pencatatan dokumen kehadiran masih diterapkan secara manual, serta jika hadir diperusahaan tersebut hanya tatap muka. Hal ini akan mendapatkan persoalan yang akan muncul nantinya. Untuk data kehadiran karyawan ini masih kurang efesien dan efektif karena menggunakan sistem manual dari pendataan karyawan mulai dari perhitungan jam hadir, jam keluar, lama kerja, keterangan tidak masuk kerja. Secara garis besar hal ini menimbulkan masalah seperti kerusakan data atau dokumen yang disimpan , serta hilang nya karena kelalaian atau miskomunikasi " human error". Dari permasalahan tersebut memunculkan gagasan untuk membuat suatu aplikasi berbasis web, yang di dalamnya dapat melakukan pengelolaan data kehadiran karyawan diperusahaan tersebut. Metodologi yang digunakan dalam pembuatan aplikasi ini adalah metode Waterfall. Bahasa pemrogramannya adalah PHP dan HTML. Untuk tampilan menggunakan CSS3 dan Jquery. Databasenya menggunakan MySQL Tools dan Editor yang digunakan ialah XAMPP for Windows 5.6.36, Viual Studio Code. Didukung dengan tersedianya jaringan internet lokal di dalam perusahaan.

\section{Tinjauan Literatur (Literature Review)}

Penelitian yang berjudul "Perancangan Sistem Absensi Online Menggunakan Android Guna Mempercepat Proses Kehadiran Karyawan Pada PT. Sintech Berkah Abadi”. Oleh Al Husain, Abdul Haqy Aji Prastian, Andre Ramadhan(2017). Perlunya desain aplikasi absensi online untuk kehadiran karyawan yang didalam lingkungan kantor, maupun yang berada diluar lingkungan kantor. Metode sistem diatas, memerlukan metode pengumpulan data sistem yang berjalan, wawancara, observasi, analisa sistem yang diusulkan, dan metode prototipe dan testing sebagai pembentukan sistem usulan yang memadai sebagai alternative solusi terbaik dari permasalahan yang ada. Metode desain sistem pendekatan terstruktur dengan activity diagram, use case diagram dan class diagram. Sistem absensi online ini merupakan rancangan sistem yang dapat memudahkan dalam urusan kehadiran karyawan. Dengan adanya sistem ini diharapkan perusahaan dapat lebih produktif dalam menghasilkan sebuah produk, karena sistem yang dapat mempermudah dan mempercepat absensi maka waktu yang dibutuhkan dalam bekerja juga sangat efisien. Hal ini dapat mepercepat antrian dalam mengabsensi karyawan. Sistem ini juga dapat menghasilkan laporan yang sangat akurat, karena data-data absensi sudah diolah oleh sistem dan direkap dengan rapih.

\section{Metode Penelitian (or Research Method)}

\subsection{Metode Pengumpulan Data}

\subsubsection{Studi Pustaka}

Pengumpulan data dengan menggunakan atau mengumpulkan sumber-sumber tertulis, dengan cara membaca, mempelajari dan mencatat hal-hal penting yang berhubungan dengan masalah yang sedang dibahas guna memperoleh gambaran secara teoritis yang dapat menunjang pada penyusunan Skripsi.

\subsubsection{Observasi}

Pengumpulan data dengan melakukan pengamatan secara langsung terhadap objek penelitian, dengan mencatat hal-hal penting yang berhubungan dengan judul Skripsi, sehingga diperoleh data yang lengkap dan akurat.

\subsubsection{Wawancara}

\section{(c) (1) (9)}


Pengumpulan data dengan cara melakukan komunikasi dan wawancara secara langsung dengan karyawan yang berada diperusahaan tersebut. untuk memperoleh data informasi yang diperlukan.

\subsubsection{Studi Dokumen}

Teknik pengumpulan data ini dilakukan dengan mengandalkan dokumen sebagai salah satu sumber data yang digunakan untuk melengkapi penelitian. Dokumen yang digunakan dapat berupa sumber tertulis, film, dan gambar atau foto.

\subsection{Metode Analisis SWOT}

Pada dasarnya, analisis SWOT Merupakan akronim atau singkatan. (Strengths, Weaknesses, Opportunities, dan Threats). Analisis SWOT terdiri dari Strength (kekuatan), Weakness (kelemahan), Opportunities (peluang), dan Threats (ancaman) yang merupakan proses perencanaan yang membantu mengatasi tantangan dan menentukan apa yang harus dituju secara keseluruhan

3.3 Metode Pengembangan

Model yang digunakan untuk perancangan aplikasi penggajian ini adalah Waterfall. Model ini digunakan karena kebutuhan sistem yang diberikan pihak perusahaan sudah sangat jelas. Model waterfall digambarkan sebagai berikut:

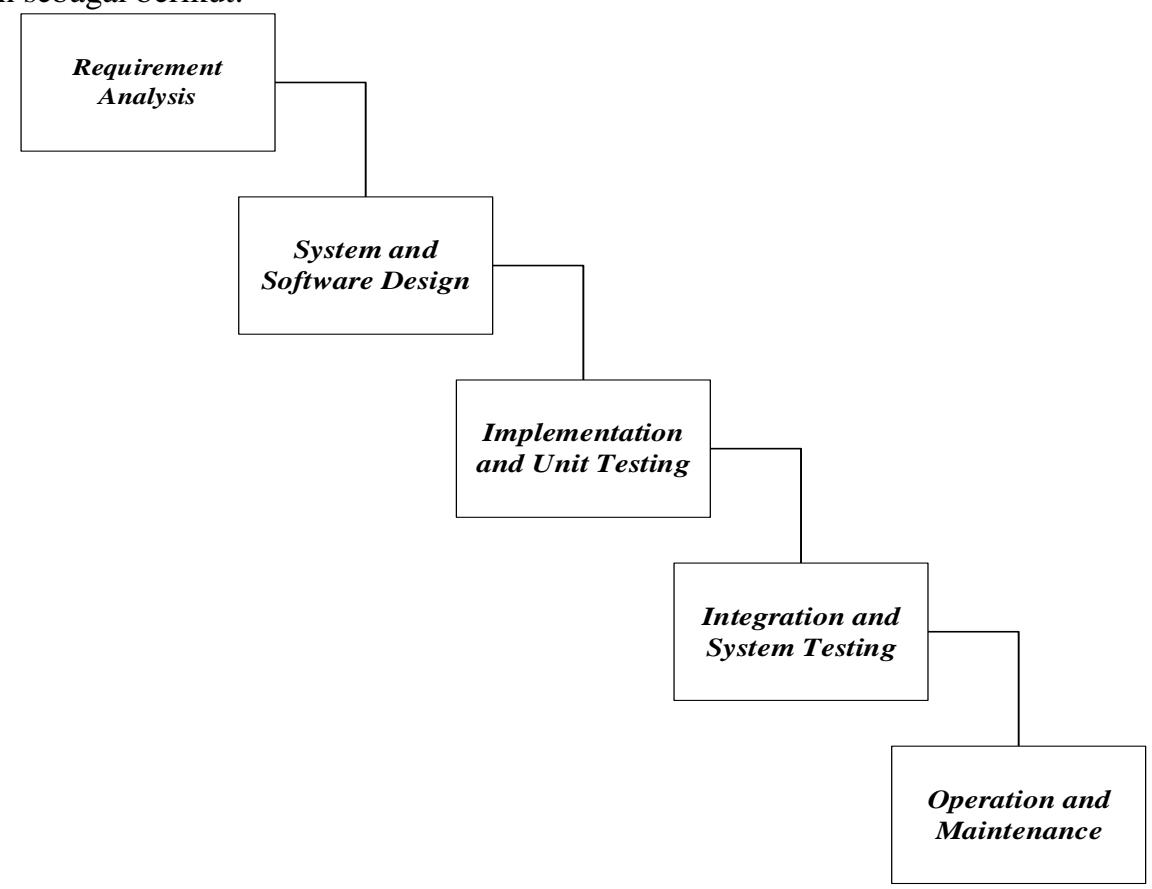

Gambar 3.1

a. Requirement Analysis

Metode Waterfall

Metode pengumpulan informasi ini dapat diperoleh dengan berbagai macam cara diantaranya, diskusi, observasi, survei, wawancara, dan sebagainya.

b. System and Software Design

Informasi mengenai spesifikasi kebutuhan dari tahap Requirement Analysis selanjutnya di analisa pada tahap ini untuk kemudian diimplementasikan pada desain pengembangan. Perancangan desain dilakukan dengan tujuan membantu memberikan gambaran lengkap mengenai apa yang harus dikerjakan. Tahap ini juga akan membantu pengembang untuk 
menyiapkan kebutuhan hardware dalam pembuatan arsitektur sistem perangkat lunak yang akan dibuat secara keseluruhan.

c. Implementation and Unit Testing

Tahap implementation and unit testing merupakan tahap pemrograman. Pembuatan perangkat lunak dibagi menjadi modul-modul kecil yang nantinya akan digabungkan dalam tahap berikutnya. Disamping itu, pada fase ini juga dilakukan pengujian dan pemeriksaan terhadap fungsionalitas modul yang sudah dibuat, apakah sudah memenuhi kriteria yang diinginkan atau belum.

d. Integration and System Testing

Setelah seluruh unit atau modul yang dikembangkan dan diuji di tahap implementasi selanjutnya diintegrasikan dalam sistem secara keseluruhan. Setelah proses integrasi selesai, selanjutnya dilakukan pemeriksaan dan pengujian sistem secara keseluruhan untuk mengidentifikasi kemungkinan adanya kegagalan dan kesalahan sistem.

e. Operation and Maintenance

Pada tahap terakhir dalam Metode Waterfall, perangkat lunak yang sudah jadi dioperasikan pengguna dan dilakukan pemeliharaan. Pemeliharaan memungkinkan pengembang untuk melakukan perbaikan atas kesalahan yang tidak terdeteksi pada tahap-tahap sebelumnya. Pemeliharaan meliputi perbaikan kesalaha, perabikan implementasi unit sistem, dan peningkatan dan penyesuaian sistem sesuai dengan kebutuhan.

3.4 Instrumen Penelitian

Dalam penelitian ini penulis menggunakan penelitian Kualitatif, Metode penelitian yang digunakan adalah metode kualitatif. "Metodologi adalah proses, prinsip, dan prosedur yang kita gunakan untuk mendekati problem dan mencari jawaban" Menurut(Gamal Thabroni, 2021). Metode penelitian kualitatif adalah penelitian yang menggunakan cara, langkah, dan prosedur yang lebih melibatkan data dan informasi yang diperoleh melalui responden sebagai subjek yang dapat mencurahkan jawaban dan perasaannya sendiri untuk mendapatkan gambaran umum yang holistik mengenai suatu hal yang diteliti. Dalam penelian ini penulis perlu mengembangakan instrumen penelitian tersebut dan penulis mendapat tiga (3) instrumen penelitian yang dimana cara ini untuk melengkapi penelitian. Adapun instrumen sebagai berikut :
a. Sistem Yang Diteliti(Input)
b. Sistem Informasi Presensi Karyawan (Output)
c. Sistem Informasi Prestasi Karyawan(Outcome)

3.5 Desain Penelitian (Sistem Yang Berjalan Saat Ini)

Pada perancangan suatu sistem diperlukan analisis yang tepat sehingga proses pembuatan sistem dapat berjalan dengan lancar dan sistem yang dibuat sesuai dengan yang diinginkan. Setelah analisis dilakukan perlu dilakukan desain sistem yang berujuan untuk memberikan gambaran tentang jalannya sistem tersebut. Selain itu desain sistem juga bertujuan untuk mempermudah penulis dalam mengimplementasikan sistem tersebut. Adapun sistem yang berjalan saat ini ada 3 sebagai berikut: 
Volume 2, Nomor 2,Oktober 2021: halaman 115-128

e-ISSN: 2807-5528

https://jurnal.amikwidyaloka.ac.id/index.php/awl

jurnal@amikwidyaloka.ac.id / editor.jurnalwidya@gmail.com

a. Flowmap Absensi

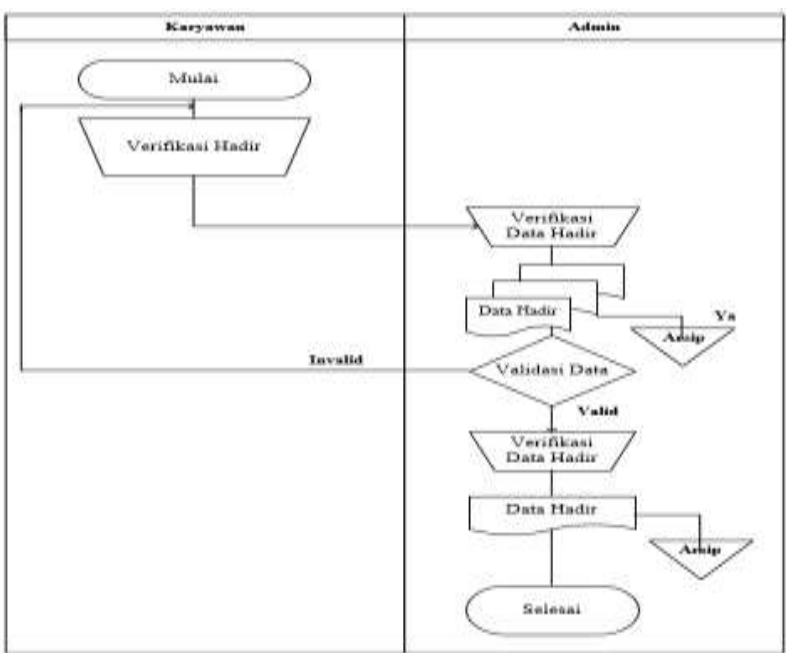

Gambar 3.2 Flowmap

b. Usecase Diagram Presensi

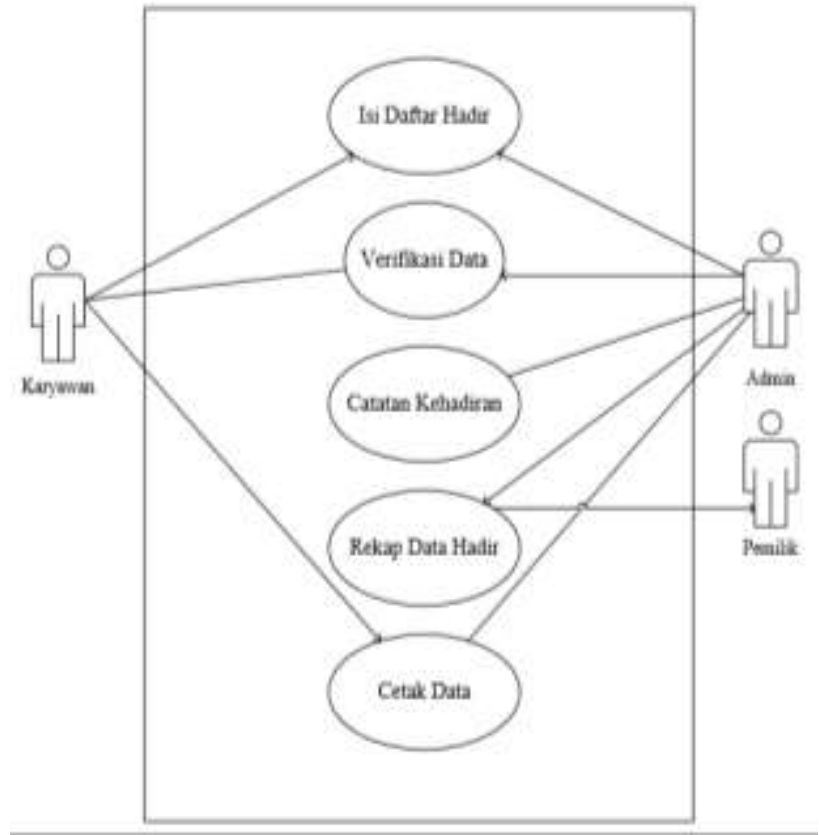

Gambar 3.3 Usecase 
Volume 2, Nomor 2,Oktober 2021: halaman 115-128

c. Activity Diagram

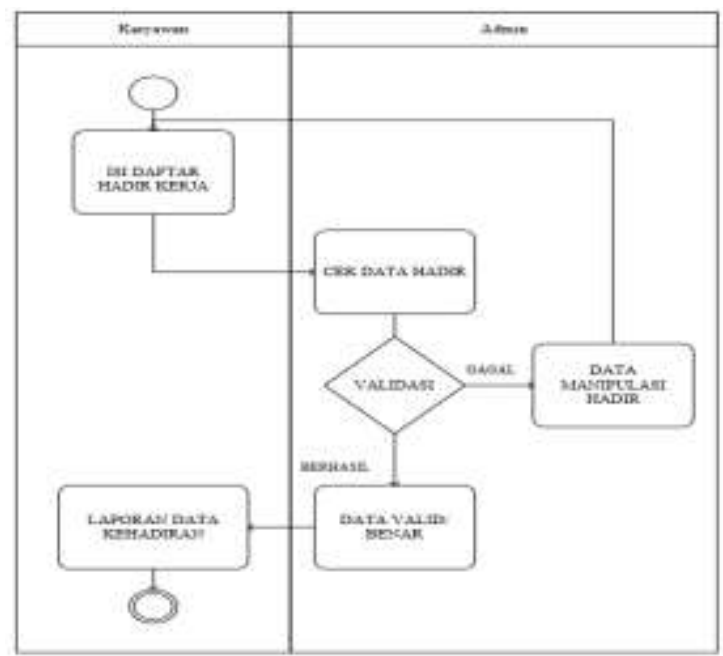

Gambar 3.4 Activity

\section{$4 \quad$ Hasil dan Pembahasan (Results and Analysis)}

4.1 Flowchart HRD \& Karyawan

Proses absensi yang diusulkan untuk PT. PWS Reinsurance Broker Indonesia menggunakan 2(dua) flowchart Hrd \& Karyawan sebagai berikut:

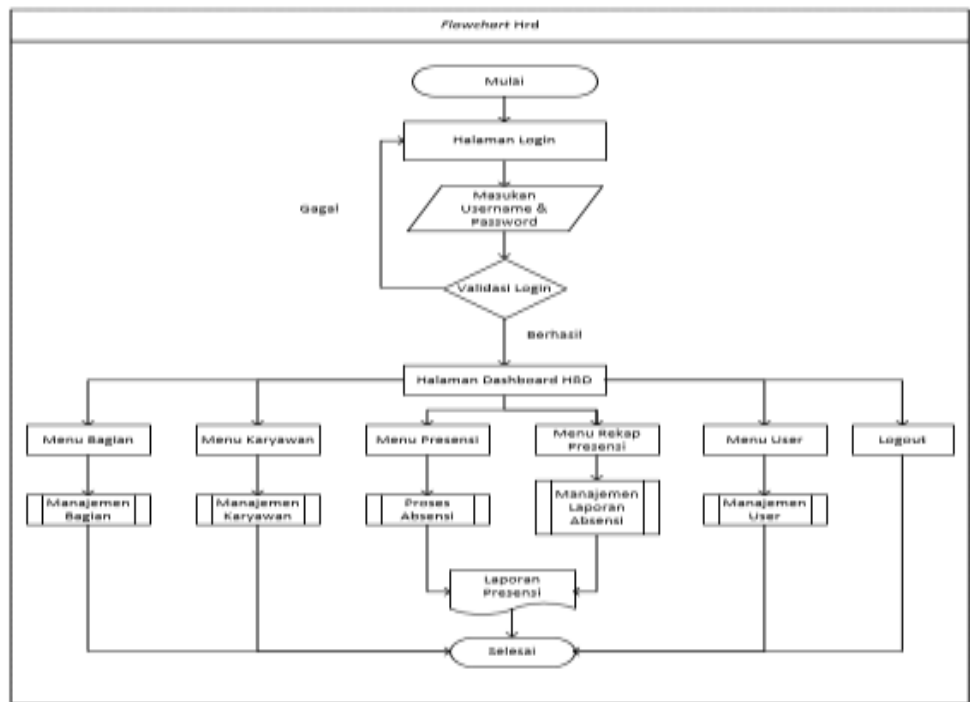

\section{Gambar 4. 1 Flowchart}

Berdasarkan gambar 4.1 terlihat sebuah flowchart dari Hrd, Langkah pertama yang di lakukan oleh aktor adalah login dan memasukan username dan password, kemudian sistem akan melakukan validasi username, password tersebut jika berhasil 
akan masuk kedalam halaman dashboard yang berisi menu bagian, menu karyawan , menu presensi, menu rekap presensi , menu user dan logout. Dimana didalam halaman dashboard tersebut dapat memproses di setiap bagiannya, untuk proses absensi dan manajemen laporan absensi akan dijadi satu dan diproses menjadi laporan presensi. Jika validasi gagal maka akan Kembali ke halaman login.

4.2 Usecase Diagram Sistem

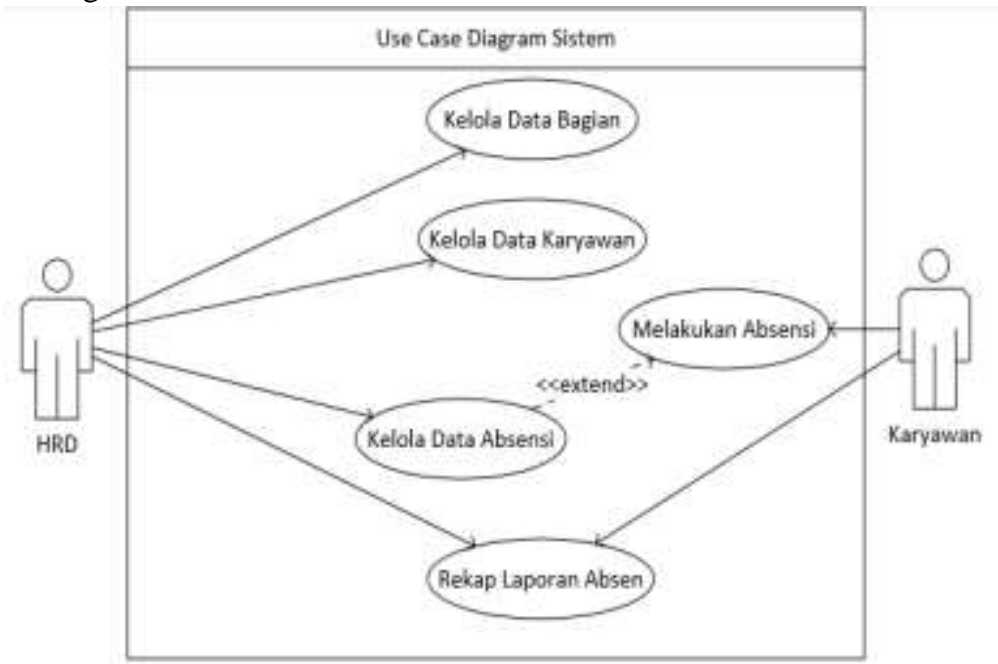

Gambar 4. 2 Usecase Diagram Sistem

Berdasarkan gambar 4.2 terlihat sebuah Use Case Diagram dari Sistem, Terdapat 2 aktor yaitu aktor Hrd dan Karyawan. Hrd bisa mengelola data bagian, data karyawan, data absensi dan data rekap laporan. Karyawan hanya bisa melakukan absensi dan merekap data laporan asbensi dirinya sendiri. 
Volume 2, Nomor 2,Oktober 2021: halaman 115-128

https://jurnal.amikwidyaloka.ac.id/index.php/awl

jurnal@amikwidyaloka.ac.id / editor.jurnalwidya@gmail.com

4.3 Class Diagram Sistem

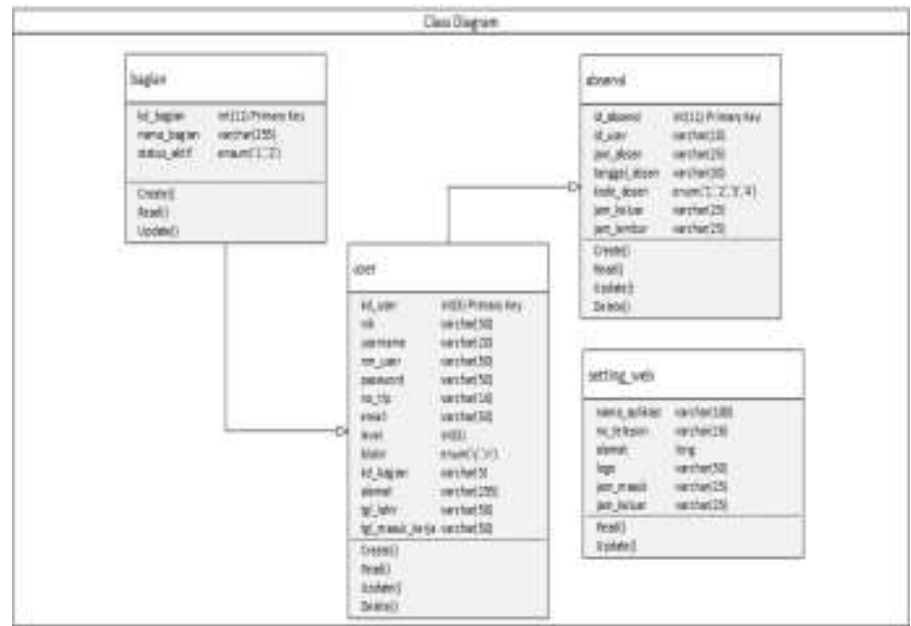

Gambar 4. 3 Class Diagram

Berdasarkan gambar 4.3 terlihat sebuah Class Diagram dari sistem dengan nama database db_absensi_pws yang memiliki 4 tabel yaitu tabel setting_web, user, bagian dan absensi.

4.4 Sequence Diagram HRD

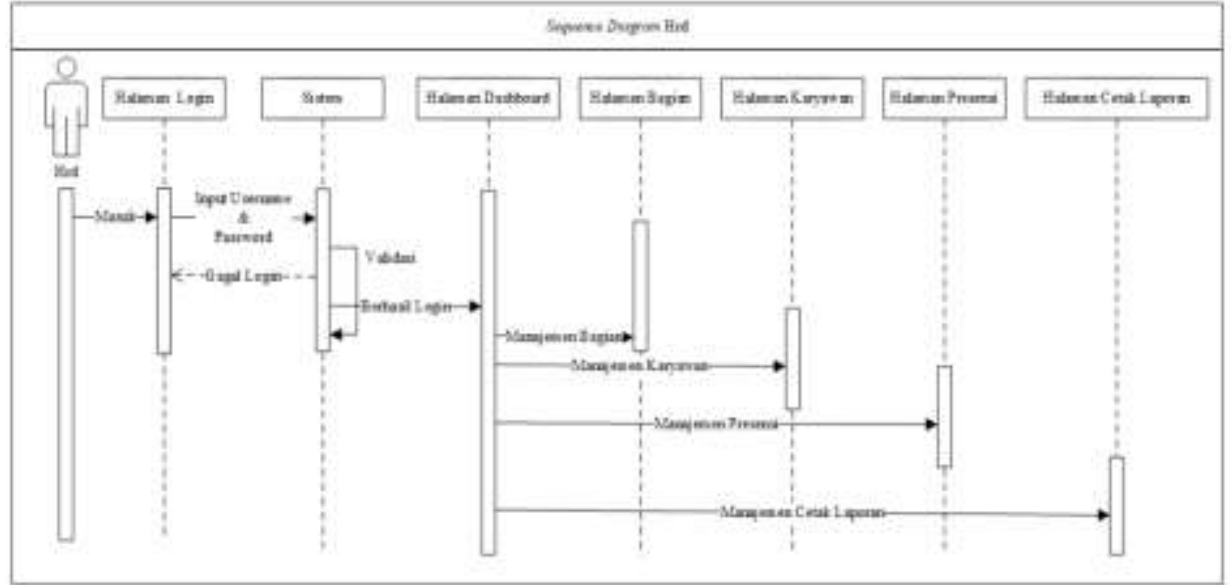

Gambar 4. 4 Sequence Diagram HRD

Berdasarkan gambar 4.4 terdapat Sequence Diagram Hrd, dapat dilihat aktor hrd memasukan username dan password. Kemudian sistem akan menerima inputan dan menyesuaikan dengan data yang ada dalam database dan kemudian melakukan validasi. Jika validasi benar maka sistem akan membawa hrd ke halaman dashboard yang didalam nya terdapat fitur bagian, karyawan, absensi dan cetak laporan. Sedangkan jika validasi gagal maka sistem akan membawa hrd kembali ke halaman login. 
Volume 2, Nomor 2,Oktober 2021: halaman 115-128

https://jurnal.amikwidyaloka.ac.id/index.php/awl

jurnal@amikwidyaloka.ac.id / editor.jurnalwidya@gmail.com

4.5 Perancangan Basis Data

Desain basis data menjelaskan nama label, tipe file, media penyimpanan yang digunakan, primary key, panjang record dll. Spesifikasi basis data yang digunakan dalam sistem yang dibangun adalah sebagai berikut:

\subsubsection{Rancangan Tabel User}

Tabel 4. 1 Rancangan Tabel User

\begin{tabular}{|c|c|c|c|}
\hline Nama Field & Type & Values & Index \\
\hline kd_user & Int & 3 & Primary Key \\
\hline Nik & Varchar & 50 & Foreign Key \\
\hline Username & Varchar & 20 & \\
\hline nm_user & Varchar & 50 & \\
\hline Password & Varchar & 50 & \\
\hline no_tlp & Varchar & 16 & \\
\hline Email & Varchar & 50 & \\
\hline Level & Int & 3 & \\
\hline Blokir & Enum & ('y','n') & \\
\hline kd_bagian & Varchar & 5 & Foreign Key \\
\hline Alamat & Varchar & 255 & \\
\hline tgl_lahir & Varchar & 50 & \\
\hline tgl_masuk_kerja & Varchar & 50 & \\
\hline
\end{tabular}

Berdasarkan tables 4.1 terdapat tabel user yaitu :

$\begin{array}{ll}\text { Nama Tabel } & \text { : user } \\ \text { Media Penyimpanan } & \text { : ssd } \\ \text { Primary Key } & \text { : id_area }\end{array}$


Volume 2, Nomor 2,Oktober 2021: halaman 115-128

https://jurnal.amikwidyaloka.ac.id/index.php/awl

jurnal@amikwidyaloka.ac.id / editor.jurnalwidya@gmail.com

4.5.2 Rancangan Tabel Seting Web

Tabel 4. 1 Rancangan Tabel Seting Web

\begin{tabular}{|l|l|l|l|}
\hline \multicolumn{1}{|c|}{ Nama Field } & \multicolumn{1}{|c|}{ Type } & \multicolumn{1}{c|}{ Values } & \multicolumn{1}{c|}{ Index } \\
\hline nama_aplikasi & Varchar & 100 & \\
\hline no_telepon & Varchar & 16 & \\
\hline Alamat & Longtext & & \\
\hline Logo & Varchar & 50 & \\
\hline jam_masuk & Varchar & 25 & \\
\hline jam_keluar & Varchar & 25 & \\
\hline
\end{tabular}

Berdasarkan tables 4.2 terdapat tabel setting_web yaitu :

$\begin{array}{ll}\text { Nama Tabel } & \text { : setting_web } \\ \text { Media Penyimpanan } & \text { : ssd } \\ \text { Primary Key } & : \text { - }\end{array}$

4.5.3 Rancangan Tabel Absensi

Tabel 4. 2 Rancangan Tabel Absensi

\begin{tabular}{|c|c|c|c|}
\hline Nama Field & Type & Values & Index \\
\hline id_absensi & Int & 11 & Primary Key \\
\hline id_user & Varchar & 10 & Foreign Key \\
\hline jam_absen & Varchar & 25 & \\
\hline tanggal_absen & Varchar & 30 & \\
\hline kode_absen & Enum & $\begin{array}{l}\left(' 1,, 2^{\prime},{ }^{\prime} 3^{\prime},\right. \\
\left.4^{\prime}\right)\end{array}$ & \\
\hline jam_keluar & Varchar & 25 & \\
\hline jam_lembur & Varchar & 25 & \\
\hline
\end{tabular}

Berdasarkan tables 4.3 terdapat tabel absensi yaitu : 


\section{Jurnal Widya}

Volume 2, Nomor 2,Oktober 2021: halaman 115-128

https://jurnal.amikwidyaloka.ac.id/index.php/awl

jurnal@amikwidyaloka.ac.id / editor.jurnalwidya@gmail.com

$\begin{array}{ll}\text { Nama Tabel } & \text { : absensi } \\ \text { Media Penyimpanan } & : \text { ssd } \\ \text { Primary Key } & \text { : id_absensi }\end{array}$

4.5.4 Rancangan Tabel Bagian

Tabel 4. 3 Rancangan Tabel Bagian

\begin{tabular}{|l|l|l|l|}
\hline \multicolumn{1}{|c|}{ Nama Field } & \multicolumn{1}{|c|}{ Type } & \multicolumn{1}{c|}{ Values } & \multicolumn{1}{c|}{ Index } \\
\hline kd_bagian & Int & 11 & Primary Key \\
\hline nama_bagian & Varchar & 255 & \\
\hline status_aktif & Enum & $($ ''1','2') & \\
\hline
\end{tabular}

Berdasarkan tables 4.4 terdapat tabel bagian yaitu :
Nama Tabel
: bagian
Media Penyimpanan
: ssd
Primary Key
: kd_bagian

4.6 Implementasi Sistem

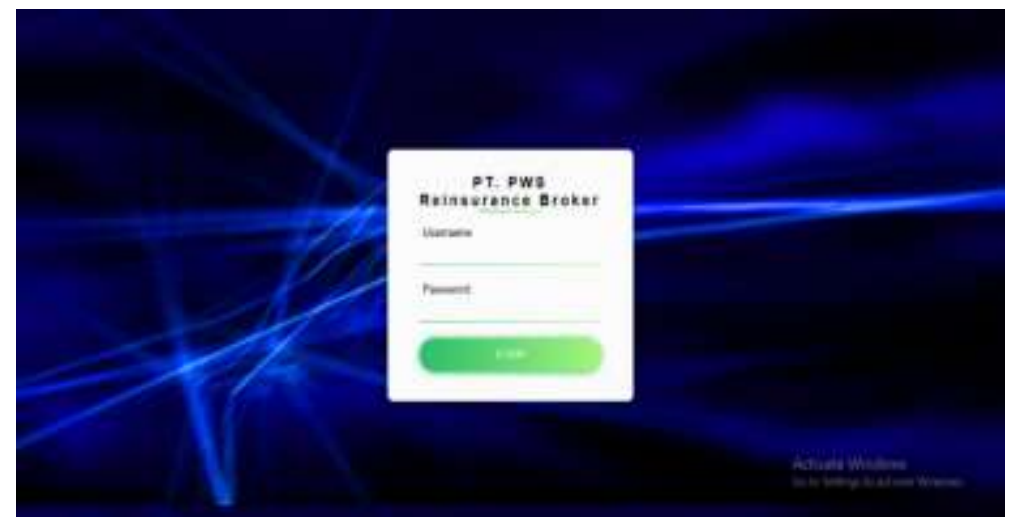

Gambar 4. 5 Layout Login

Berdasarkan gambar 4.5 terdapat tampilan form login. Form ini berfungsi untuk masuk kedalam sistem dengan cara memasukan username dan password. 
https://jurnal.amikwidyaloka.ac.id/index.php/awl

jurnal@amikwidyaloka.ac.id / editor.jurnalwidya@gmail.com

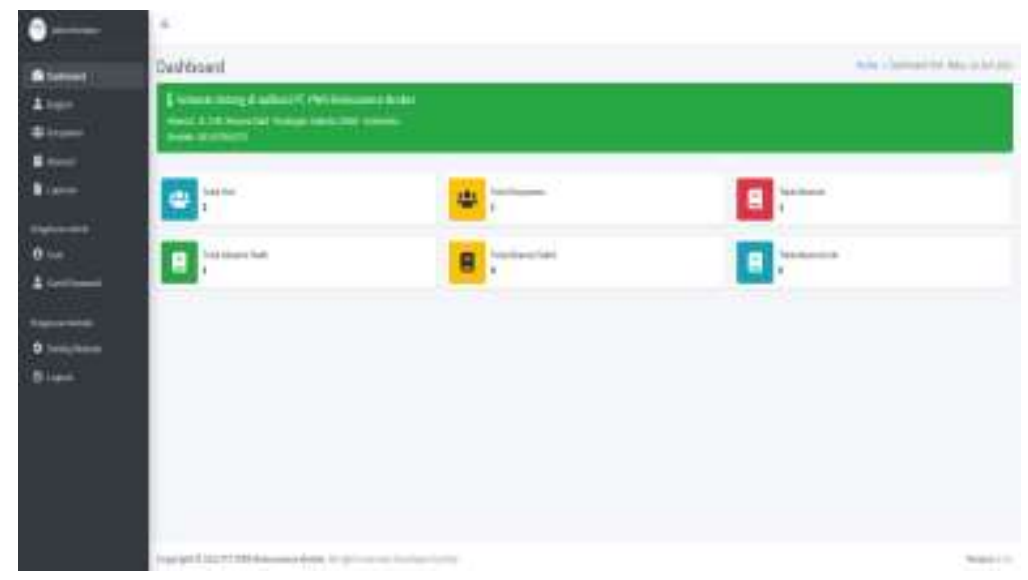

Gambar 4. 6 Layout Dashboard HRD

Berdasarkan gambar 4.6 terdapat tampilan form dashboard hrd. Form ini hanya berada di level hrd, didalam dashboard ini terlihat seluruh fitur yang tersedia di level hrd.
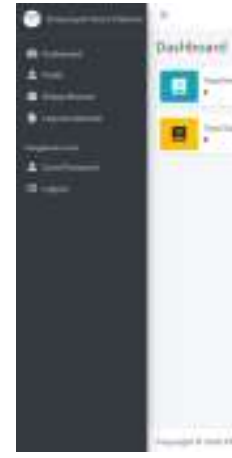

Gambar 4. 7 Layout Dashboard Karyawan

Berdasarkan gambar 4.7 terdapat tampilan form karyawan. Form ini hanya berada di

\section{Kesimpulan (or Conclusion)}

Berdasarkan dari penelitian yang telah dilaksankan mengenai "Perancangan Aplikasi Sistem Presensi Karyawan Berbasis Web Di PT. PWS Reinsurance Broker Indonesia” maka dapat disimpulkan bahwa Sistem pencatatan kehadiran karyawan sedang berjalan masih menggunakan sistem atau cara manual, hal ini yang bisa seringkali terjadi kesalahan. Dan Setelah adanya sistem presensi yang diusulkan oleh penulis dapat membantu mengatasi kesalahan dalam pendataan dan menjadikan kegiatan arsip sedikit berkurang karena semua sudah bersistem.

\section{Referensi (Reference)}

[1] Adani, M. R. (2020). Apa itu MySQL: Pengertian, Fungsi, beserta Kelebihan. Www.Sekawanmedia.Co.Id.

[2] Andalia, F., \& Setiawan, E. B. (2015). Pengembangan Sistem Informasi Pengolahan Data Pencari Kerja Pada Dinas Sosial Dan Tenaga Kerja Kota Padang. Komputa : Jurnal Ilmiah Komputer Dan Informatika, 4(2), 93-97. https://doi.org/10.34010/komputa.v4i2.2431

[3] Ansori, A. (2020). Pengertian UML (Unified Modeling Language) : Jenis, Tujuan, Notasi, dan Contohnya. https://www.ansoriweb.com/2020/03/pengertian-uml.html

[4] Husain, A., Prastian, A. H. A., \& Ramadhan, A. (2017). Perancangan Sistem Absensi Online Menggunakan Android Guna Mempercepat Proses Kehadiran Karyawan Pada PT. Sintech Berkah Abadi. Technomedia Journal, 2(1), 105-116. https://doi.org/10.33050/tmj.v2i1.319

[5] Hutahaean, J. (2015). Konsep Sistem Informasi. CV. Budi Utama. https://books.google.co.id/books?hl=id\&lr=\&id=o8LjCAAAQBAJ\&oi=fnd\&pg=PR7\&dq=Jeperson+Hut 
ahaean.+2015.+"KONSEP+SISTEM+INFORMASI".\&ots=t-

s8xINTgH\&sig=8BDKGgcsGrv00vxCDNp7SG-si68\&redir_esc=y\#v=onepage \&q\&f=false

[6] Ii, B. A. B., \& Pustaka, T. (2005). Gambar 2.1. Model Umum Sistem 8. 8-19.

[7] Manganugrahana, Y. (2019). Pengertian XAMPP Lengkap dengan Cara Menggunakannya (Terbaru). https://www.niagahoster.co.id/blog/cara-menggunakan-xampp/\#Pengertian_XAMPP

[8] Mountaines, P. E., Satoto, K. I., \& Kridalukmana, R. (2013). Pengembangan Aplikasi Berbasis Web untuk Menampilkan Absensi dan Nilai Akhir Peserta Didik (Studi Kasus di SMP Negeri 32 Semarang). Jurnal Teknologi Dan Sistem Komputer, 1(4), 129-144. https://doi.org/10.14710/jtsiskom.1.4.2013.129-144

[9] Saragi Napitu, R. C., Ramadhani, I. A., \& Firman, F. (2020). Perancangan Sistem Absensi Berbasis Web pada Program Studi PTI UNIMUDA Sorong. JURNAL PETISI (Pendidikan Teknologi Informasi), 1(2), 1-7. https://doi.org/10.36232/jurnalpetisi.v1i1.453

[10] Subiantoro, \& Sardiarinto. (2018). Perancangan Sistem Absensi Pegawai Berbasis Web. Jurnal Swabumi, 6(2), 184-189.

[11] Triyono, T., Safitri, R., \& Gunawan, T. (2018). Perancangan Sistem Informasi Absensi Guru Dan Staff Pada Smk Pancakarya Tangerang Berbasis Web. SENSI Journal, 4(2), 153-167. https://doi.org/10.33050/sensi.v4i2.638

[12] Adi Mardian, Thomas Budiman, Rachmawaty Haroen; Verdi Yasin (2021), Perancangan Aplikasi Pemantauan Kinerja Karyawan Berbasis Android di PT. Salestrade Corp. Indonesia, "Jurnal Manajemen Informatika Jayakarta", E-ISSN : 2797-0930 (Online), P-ISSN : 2746-5985 (Print), Volume 1, Nomor 3,Juli 2021, halaman 169-185, DOI: 10.52362/jmijayakarta.v1i3.481, URL Publikasi: http://journal.stmikjayakarta.ac.id/index.php/JMIJayakarta/article/view/481

[13] Nandang Mulyana, Agus Sulistyanto, Verdi Yasin (2021), Perancangan sistem informasi pengelolaan aset it berbasis web pada pt mandiri axa general insurance, "Jurnal Manajemen Informatika Jayakarta", EISSN : 2797-0930 (Online), P-ISSN : 2746-5985 (Print), Volume 1, Nomor 3, Juli 2021, halaman 243257, DOI: 10.52362/jmijayakarta.v1i3.498, URL Publikasi: http://journal.stmikjayakarta.ac.id/index.php/JMIJayakarta/article/view/498

[14] Maulia Usnaini, Verdi Yasin, Anton Zulkarnain Sianipar (2021), Perancangan sistem informasi inventarisasi aset berbasis web menggunakan metode waterfall, "Jurnal Manajemen Informatika Jayakarta", E-ISSN : 2797-0930 (Online), P-ISSN : 2746-5985 (Print) Volume 1, Nomor 1,Februari 2021, halaman 36-55, DOI: 10.52362/jmijayakarta.v1i1.415, URL Publikasi: http://journal.stmikjayakarta.ac.id/index.php/JMIJayakarta/article/view/415

[15] Putri Setiani, Ifan Junaedi, Anton Zulkarnain Sianipar, Verdi Yasin (2021), Perancangan sistem informasi pelayanan penduduk berbasis website di rw 010 Kelurahan Keagungan Kecamatan Tamansari - Jakarta Barat. "Jurnal Manajemen Informatika Jayakarta", E-ISSN : 2797-0930 (Online), P-ISSN : 27465985 (Print) Volume 1, Nomor 1,Februari 2021, halaman 20-35, DOI: 10.52362/jmijayakarta.v1i1.414, URL Publikasi: http://journal.stmikjayakarta.ac.id/index.php/JMIJayakarta/article/view/414

[16] Benni Triyono, Sri Purwanti, Verdi Yasin (2017) "Rekayasa Perangkat Lunak Sistem Informasi Pengiriman Dan Penerimaan Surat Atau Paket Berbasis Web", Journal of Information System, Applied, Management, Accounting and Research, e-ISSN: 2598-8719. p-ISSN: 2598-8700.Vol.1 No.1 (30 Desember 2017) p46-53 http://journal.stmikjayakarta.ac.id/index.php/jisamar/article/view/12

[17] Verdi Yasin, Muhammad Zarlis, Mahyuddin K.M. Nasution (2018) "Filsafat Logika Dan Ontologi Ilmu Komputer", Journal of Information System, Applied, Management, Accounting and Research, eISSN: 2598-8719. p-ISSN: 2598-8700.Vol.2 No.2 (19 Juni 2018) p68-75 http://journal.stmikjayakarta.ac.id/index.php/jisamar/article/view/39

[18] Julinda Maya Paramudita, Verdi Yasin (2019) "Perancangan Aplikasi Sistem Penyewaan Alat Berat “, Journal of Information System, Applied, Management, Accounting and Research, e-ISSN: 25988719. p-ISSN: 2598-8700.Vol.3 No.1 (20 Februari 2019) p23-29 http://journal.stmikjayakarta.ac.id/index.php/jisamar/article/view/73

[19] Muryan Awaludin, Verdi Yasin (2020) "Application Of Oriented Fast And Rotated Brief (Orb) And Bruteforce Hamming In Library Opencv For Classification Of Plants", Journal of Information System, Applied, Management, Accounting and Research, e-ISSN: 2598-8719. p-ISSN: 2598-8700.Vol.4 No.3 (14 Agustus 2020) p51-59 http://journal.stmikjayakarta.ac.id/index.php/jisamar/article/view/247

[20] Ifan Junaedi, Dimas Abdillah, Verdi Yasin (2020) "Analisis Perancangan Dan Pembangunan Aplikasi Business Intelligence Penerimaan Negara Bukan Pajak Kementerian Keuangan RI”, Journal of

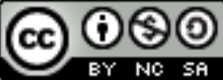

JURNAL WIDYA This work is licensed under a Creative Commons Attribution-NonCommercial- 
Information System, Applied, Management, Accounting and Research, e-ISSN: 2598-8719. p-ISSN: 2598-8700.Vol.4 No.3 (14 Agustus 2020) p88-101 http://journal.stmikjayakarta.ac.id/index.php/jisamar/article/view/249

[21] Verdi Yasin (2012) 'Rekayasa Perangkat Lunak Berorientasi Objek”, Penerbit: Mitra Wacana Media, Jakarta-Indonesia.

[22] Anis Rohmadi, Verdi Yasin (2020) "Desain Dan Penerapan Website Tata Kelola Percetakan Pada CV Apicdesign Kreasindo Jakarta Dengan Metode Prototyping", Journal of Information System, Informatics and Computing._E-ISSN: 2597-3673 (Online), P-ISSN: 2579-5201 (Print) Vol. 4 No.1, June 22, 2020. Pp.70-85 http://journal.stmikjayakarta.ac.id/index.php/jisicom/article/view/210

[23] Septian Cahyadi, Verdi Yasin, Mohammad Narji, Anton Zulkarnain Sianipar (2020) "Perancangan Sistem Informasi Pengiriman Dan Penerimaan Soal Ujian Berbasis Web ( Studi Kasus: Fakultas Komputer Universitas Bung Karno)", Journal of Information System, Informatics and Computing._E-ISSN: 2597-3673 (Online), P-ISSN: 2579-5201 (Print) Vol. 4 No.1, June 22, 2020. Pp.1-16 http://journal.stmikjayakarta.ac.id/index.php/jisicom/article/view/199

[24] Ifan Junaedi, Ndaru Nuswantari, Verdi Yasin (2019) "Perancangan Dan Implementasi Algoritma C4.5 Untuk Data Mining Analisis Tingkat Risiko Kematian Neonatum Pada Bayi”, Journal of Information System, Informatics and Computing._E-ISSN: 2597-3673 (Online), P-ISSN: 2579-5201 (Print) Vol. 3 No.1, February 13, 2019. Pp.29-44. http://journal.stmikjayakarta.ac.id/index.php/jisicom/article/view/203

[25] Verdi Yasin, Anindra Ramdhan Nugraha, Muhammad Zarlis, Ifan Junaedi (2018) "Smart System Of Fast Internet Access Development Using Backbone Network Method", Journal of Information System, Informatics and Computing. E-ISSN: 2597-3673 (Online), P-ISSN: 2579-5201 (Print) Vol. 2 No. 2, December 31, 2018. Pp.26-34. http://journal.stmikjayakarta.ac.id/index.php/jisicom/article/view/198

[26] Ito Riris Immasari, Verdi Yasin (2019) "Penggunaan Metode Analytic Hierarchy Process Untuk Menganalisis Faktor-Faktor Yang Mempengaruhi Pemilihan Calon Legislatif Di Dprd Ii Kota Tangerang", Journal of Information System, Informatics and Computing. E-ISSN: 2597-3673 (Online), P-ISSN: 2579-5201 (Print) Vol. 3 No. 2, December 10, 2019. Pp.53-58. http://journal.stmikjayakarta.ac.id/index.php/jisicom/article/view/139

[27] Verdi Yasin, Muhammad Zarlis, Tulus, Erna Budhiarti Nababan, Poltak Sihombing (2019) "Rancangan Miniatur Otomatisasi Bel Listrik Pada Gerbang Pintu Menggunakan Microkontroler Atmega8535", Journal of Information System, Informatics and Computing. E-ISSN: 2597-3673 (Online), P-ISSN: 2579-5201 (Print) Vol. 3 No. 1, February 13, 2019. Pp.13-20 http://journal.stmikjayakarta.ac.id/index.php/jisicom/article/view/68

[28] Anggeri S. Nurjaman, Verdi Yasin (2020) "Konsep Desain Aplikasi Sistem Manajemen Kepegawaian Berbasis Web Pada PT. Bintang Komunikasi Utama ", Journal of Information System, Informatics and Computing. E-ISSN: 2597-3673 (Online), P-ISSN: 2579-5201 (Print) Vol. 4 No. 2, December 28, 2020. Pp.143-174_ http://journal.stmikjayakarta.ac.id/index.php/jisicom/article/view/363

[29] Verdi Yasin, Azhar Ahmad Riza, Rumadi Hartawan (2017) "Pengembangan Aplikasi Pemulihan Layanan Bencana Sistem Informasi Peneriman Negara Bukan Pajak Online Di Lingkungan Kementerian Keuangan Republik Indonesia", Journal of Information System, Informatics and Computing. E-ISSN: 25973673 (Online), P-ISSN: 2579-5201 (Print) Vol. 1 No. 1, September 20, 2017. Pp.33-56. http://journal.stmikjayakarta.ac.id/index.php/jisicom/article/view/4 